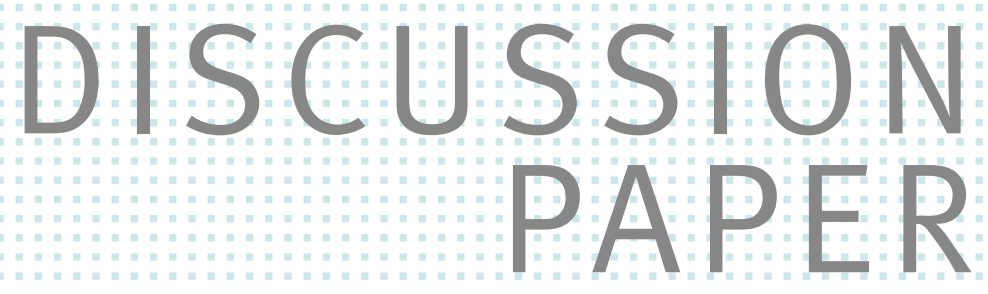

// ROLAND KUBE, KATHRINE VON GRAEVENITZ, ANDREAS LÖSCHEL, AND PHILIPP MASSIER

\title{
Do Voluntary Environmental Programs Reduce Emissions? EMAS in the German Manufacturing Sector
}




\title{
Do voluntary environmental programs reduce emissions? EMAS in the German manufacturing sector
}

Roland Kube ${ }^{a,}{ }^{*}$, Kathrine von Graevenitz ${ }^{b}$, Andreas Löschel ${ }^{a, b, c, d}$, and Philipp Massier ${ }^{b}$

January 2019

a University of Münster, Münster, Germany

b ZEW - Leibniz Centre for European Economic Research, Mannheim, Germany

c Fraunhofer Center for Economics of Materials (CEM), Halle, Germany

d Research Institute for Global Value Chains, University of International Business and Economics, Beijing, China

* Corresponding Author at: University of Münster, Am Stadtgraben 9, 48143 Münster, Germany E-mail address: roland.kube@wiwi.uni-muenster.de

\begin{abstract}
Voluntary environmental management programs for firms have become an increasingly popular instrument of environmental policy. However, the literature's conclusion on the effectiveness of such programs is ambiguous, and for the European region there is a lack of evidence based on a large control group. We seek to fill this gap with an evaluation of the Eco-Management and Audit Scheme (EMAS), introduced in 1995 by the European Union as a premium certification of continuous pro-environmental efforts above regulatory minimum standards. It is more demanding than other voluntary programs due to annual public reports of the environmental performance and targets for improvements. We use official firm-level production census data on the German manufacturing sector, a major energy consumer and emitter in Europe. To account for the self-selection of firms, we combine the Coarsened Exact Matching approach with a Difference-in-Differences estimation. Our results do not suggest reductions of firms' $\mathrm{CO}_{2}$ intensity and energy intensity neither before nor after certification. Moreover, program participants do not increase renewable energy consumption or investments into the protection of the environment and climate. Our results are robust to a variety of checks and call into question the effectiveness of the EMAS program concerning these particular outcome variables.
\end{abstract}

\section{Highlights:}

- We evaluate the EMAS program in Germany using production census firm-level data.

- Matching Difference-in-Differences estimation accounts for self-selection of firms.

- The program mainly attracts large and energy-intensive producers.

- We find no impact on $\mathrm{CO}_{2}$ and energy intensity, renewable usage or eco-investments.

Keywords: Voluntary Environmental Programs; Firm-level Energy Behavior; Matching Difference-inDifferences

JEL classification: Q58, Q54, Q48 


\section{1) Introduction}

Next to the deployment of renewable energy sources, a more efficient use of energy is essential for reaching national climate policy targets as committed under the Paris Agreement. Energy efficiency improvements are the main factor that attenuates global greenhouse gas emissions growth, counteracting rising energy demand due to income and population growth (IEA, 2017).

From a firm perspective, an efficient use of energy is incentivized by energy costs and environmental regulation, such as fuel taxes, standards or emissions trading. However, empirical studies also highlight the role of management quality and practices for industrial energy efficiency and respective $\mathrm{CO}_{2}$ emissions (Bloom et al., 2010, Martin et al., 2012, Boyd and Curtis, 2014, Löschel et al., 2017). In the economics literature, untapped potential for cost-efficient energy savings is often denoted as an "energy-efficiency gap" (IEA, 2015, Jaffe and Stavins, 1994, Allcott and Greenstone, 2012). Common explanations for the existence of this phenomenon are imperfect information, transaction costs, as well as uncertainty about future energy costs and regulation (Gerarden et al., 2017).

Voluntary environmental management programs for firms are a popular instrument of environmental policy as an alternative to more stringent regulations. The core idea is to provide a credible certification of firms' pro-environmental efforts and overcompliance with regulatory minimum standards. An underlying assumption is that firms would profit from an environmentally friendly image, e.g. by tapping into consumers' willingness to pay for environmentally friendly production. Such management programs should then reduce remaining inefficiencies in resource usage and spur pro-environmental behavior at low enforcement costs (Barla, 2007). In this paper, we examine whether voluntary programs effectively reduce energy use and respective $\mathrm{CO}_{2}$ emissions by firms.

The Eco-Management and Audit Scheme (EMAS) certification for plants is a prime example of a voluntary measure. The program addresses the complete environmental footprint of an organization, i.e. local air, water, noise and land pollution as well as energy use and resulting greenhouse gas emissions. Introduced by the European Union (EU) in 1995, EMAS is subject to the legal system of the $\mathrm{EU}$ and its member states, in contrast to a private sector initiative. For certification, a plant requires an initial assessment of its environmental impact, an environmental policy for the plant, and an action plan for improvements. However, what distinguishes EMAS as being more demanding than other voluntary programs is the obligation to publish annual reports on the environmental performance. Therein plants have to define own targets for improvements and explicitly state strategies and measures to achieve these targets. The program does not prescribe the ambitiousness of these targets, which may lead to certification despite a business-as-usual effort. Yet, the commitment and a systematic review of the plant's resource usage may ultimately translate into improvements.

Despite a growing impact evaluation literature, the conclusion on the effectiveness of such voluntary programs is ambiguous. The wide heterogeneity in program design, pollutants addressed and distinct regional and institutional settings make it hard to generalize the results. Well-studied programs include the U.S. EPA's 33/50 (e.g. Arora and Cason, 1996, Carrión-Flores et al., 2013, Gamper-Rabindran, 2006, Khanna and Damon, 1999, Vidovic and Khanna, 2007) and the private sector ISO14001 norm (e.g. Arimura et al., 2008, Barla, 2007, Nakamura et al., 2001). For the Strategic Goals program among firms in the U.S. metal industry, Brouhle et al. (2009) report little, if any, additional emissions reductions. Dasgupta et al. (2000) suggest that subsidies for environmental management in Mexico were beneficial for compliance, whereas Blackman et al. (2010) find no lasting impact of the Mexican Clean Industry Program on environmental performance. 
These studies mostly investigate the effect on toxic releases as well as local air and water pollution, and find mixed results. The overall conclusion for the effectiveness of programs with a particular focus on greenhouse gas emissions is, however, less promising. For the U.S. programs Climate Wise and 1605(b), Pizer et al. (2011) find no substantial effects on firm emissions and energy costs respectively. Kim and Lyon report that 1605 (b) program participants even increased their $\mathrm{CO}_{2}$ intensity while reporting reductions. A study on the Canadian Greenhouse Gas program VCR asserts no difference in reported emissions at the end of the program period (Brouhle and Harrington, 2010).

For the European region, the empirical evidence for voluntary programs is rather scarce. This is surprising given that the EU is considered as a major industrial economy with relatively stringent environmental policy in place (Bracke et al., 2008). The EMAS program has been subject to a variety of prior studies, yet to the best of our knowledge, there is no study evaluating participation with actual data on environmental performance. Bracke et. al (2008) investigate decisive financial characteristics of European firms for EMAS based on Bureau-van-Dijk firm-level data. Several studies evaluate EMAS via firm surveys with self-reported evidence, e.g. regarding product and process innovations (Frondel et al., 2004, Rennings et al., 2006) or managers' perception of the program's effectiveness (Iraldo et al., 2009), and generally find a positive influence on environmental innovations and performance.

We seek to fill this gap with an assessment of the program's effectiveness regarding firms' actual environmental performance. Our evaluation of the voluntary EMAS program also delivers policy relevant insights for the latest German climate policy measure that mandates energy audits for large firms in Germany since 2015 (Federal Ministry for Economic Affairs and Energy 2014, §§ 8 - 8d EDL-G, and Article 8 of the EU Energy Efficiency Directive (2012/27/EU)). As the empirical evidence for such mandatory audits is scarce (e.g. Fleiter et al., 2012a, Fleiter et al., 2012b) and EMAS certification fulfills the requirements, our study of a voluntary audit program may provide insight into the potential impact of mandatory audits. Although EMAS targets a variety of environmental indicators, we investigate $\mathrm{CO}_{2}$ and energy intensity as the main outcome, as well as the use of renewable energy and investments into environmental protection. Our analysis focuses on the German manufacturing sector, which is directly responsible for at least $20 \%$ of national Greenhouse Gas Emissions (Federal Environment Agency 2016a). For that purpose we link the EMAS Register with the official firm-level production census dataset AFiD (Amtliche Firmendaten für Deutschland - Official firm data for Germany) provided by the Research Data Centre of the Federal Statistical Office and Statistical Offices of the Länder. Our firm panel covers the years 1995-2014 and contains a wide set of economic indicators, energy consumption by energy source and environmental protection investment activity. This highly reliable dataset is confidential and has been utilized for previous studies on the effects of energy and climate policy (e.g. Löschel et al., 2018, Lutz, 2016).

In order to assess the EMAS program it is necessary to understand why a plant or firm may expect a positive net benefit of participation and what kind of firms select to enter the program. Our summary statistics show that the covariate distribution across participation status differs substantially. Firms with EMAS certified plants are larger, more energy and emissions intensive and show larger revenues and exports than non-certified firms do. Especially in early years, the program attracted firms with high policy relevance, i.e. relatively large energy consumers and emitters. The share of multinational corporations with multiple plants is larger among EMAS participants. Often, these firms have their own electricity generation capacities and a higher propensity to invest into the protection of the environment and climate.

To account for observable differences in characteristics of certified and non-certified firms, our empirical strategy is to pre-process the data (Ho et al., 2007) via matching. We then estimate the Difference-in-Differences of outcomes, as this method has become well established in the program 
evaluation literature (e.g. Blackman et al., 2010, Fowlie et al., 2012, and Löschel et al., 2018). We apply the Coarsened Exact Matching approach as proposed by lacus et al. $(2011,2012)$, who show that its statistical properties are preferable to other matching methods, such as Propensity Score Matching (Rosenbaum and Rubin, 1983, Dehejia and Wahba, 2002) or Nearest-Neighbor Matching.

Overall, we find no robust evidence of an effect on $\mathrm{CO}_{2}$ intensity and energy intensity. One explanation for our findings might be that EMAS firms do not mainly target energy usage and $\mathrm{CO}_{2}$ emissions with EMAS. Instead, participants may focus their efforts on other pollutants addressed by the program, such as local air, water and land pollution, which we do not observe in our dataset. However, we also find no robust evidence of higher investments into the protection of the environment and climate by EMAS firms. The same holds for the use of renewable energy sources. A conservative interpretation of our findings is that the effectiveness of EMAS - above and beyond other (unobservable) certification schemes such as ISO 14001 - is questionable.

The analysis continues with a description of the EMAS program and insights from existing research on voluntary measures. In Section 3, we present the data and explain our empirical approach. In Section 4 , we present and discuss the main results and Section 5 provides checks for robustness. Section 6 discusses the findings.

\section{2) The EMAS program}

The Eco Management and Audit Scheme (EMAS) was developed by the European Commission (Council Regulation No 1836/93) and implemented in Germany in 1995. ${ }^{1}$ EMAS is a public voluntary regulation that is integrated in the legal system of the EU and its member states, in contrast to other private sector initiatives like the ISO 14001 norm.

An EMAS certification requires an initial inspection of the plant site by an external auditor with a systematic review of the plant's environmental impact regarding resource usage and emissions. On this basis, the plant has to set up an environmental management system, essentially a management tool that is based on the Plan-Do-Check-Act cycle with the following steps: Step 1 (Plan): defining an environmental policy with targets and projects, Step 2 (Do): operational implementation and appointment of an environmental officer in charge and involvement of employees, Step 3 (Check): management review of progress, and Step 4 (Act): taking corrective action where necessary.

This subset of requirements is similar to the more popular ISO 14001 certification $^{2}$ and was harmonized under the EMAS II revision (EG Nr. 761/2001). Whereas ISO 14001 is often considered a necessity in the market place, EMAS is generally perceived as the "premium" certification and a stronger signal for actual environmental responsibility (Neugebauer, 2012, Bracke et al., 2008, Arimura

\footnotetext{
${ }^{1}$ Gesetz zur Ausführung der Verordnung (EG) Nr. 1221/2009 des Europäischen Parlaments und des Rates vom 25. November 2009 über die freiwillige Teilnahme von Organisationen an einem Gemeinschaftssystem für Umweltmanagement und Umweltbetriebsprüfung und zur Aufhebung der Verordnung (EG) Nr. 761/2001, sowie der Beschlüsse der Kommission 2001/681EG und 2006/193/EG. The EMAS certification system is administered by the Umweltgutachterausschuss, a subsidiary of the Federal Ministry of the Environment. EMAS auditors also need to be accredited by the DAU GmbH (Deutsche Akkreditierungs- und Zulassungsgesellschaft für Umweltgutachter $\mathrm{mbH}$ ).

${ }^{2}$ Because of relatively larger effort and costs, the number of EMAS registered organizations in Germany as of 2017 (about 1,213, EMAS Register) is smaller than ISO14001 certifications (about 8,000, Federal Environment Agency, 2017). According to a survey by the Federal Environment Agency (2013), about half of EMAS participants are also ISO14001 certified.
} 
et al., 2011). This is owing to its additional requirements: EMAS application further demands annual public reports on the current environmental performance and the definition of own targets for improvements and statements of particular strategies for achievement. Reports have to be accessible to the public and updated annually. Compliance with self-set targets is mandatory for continuous certification. The plant enters the EMAS Register when the initial statement is positively evaluated for plausibility by external auditors. Each year, the environmental reports are to be validated and the plant is to be inspected every three years.

In phone interviews with several auditors as of February 2018, we gained a better understanding of the certification routine and best practice examples. Participating firms are encouraged to increase their ambition if auditors find targets to be in reach under business-as-usual effort. However, it was pointed out that, rather than the targets, the program takes effect from the commitment to allocate extra resource to exploring means of improvement and setting timelines. Further, it was stated that firms do not immediately lose their certification when a target is missed, as long as the firm can plausibly explain the reason to the auditor, e.g. due to an increase in production or higher than expected costs. Potentially, such shortcomings can be compensated by further efforts in other parts of the environmental strategy. Almost all firms leaving the program were said to do so owing to the costs of staying in the program, which is essentially larger for small and medium enterprises. However, the EMAS certification is invalidated when a violation of environmental laws is detected.

With the latest EMAS III revision (EG Nr. 1221/2009), that came into effect in January 2010, the reporting of environmental performance was harmonized with key performance indicators, e.g. energy use or greenhouse gas emissions, and the program was no longer restricted to EU member states.

\section{Reasons for participation}

In order to assess the EMAS program it is necessary to understand why firms would expect a positive net benefit from participation and what kind of firms are attracted to the voluntary program.

In a survey by the Federal Environment Agency (2013), German EMAS manufacturing firms state initial costs stated of $20 \mathrm{~K} €$ at the median and ranging up to $75 \mathrm{~K} €$ for larger firms. Estimated variable costs are less than $10 \mathrm{~K} €$ on average and only exceeds $20 \mathrm{~K} €$ for $20 \%$ of respondents. ${ }^{3}$ In contrast, average estimated cost savings are more than $10 \mathrm{~K} €$ per year, also increasing with firm size, and mostly attributed to improved resource efficiency, especially regarding energy usage.

The existing literature suggests that firms mainly join EMAS due to firm internal motivation or due to regulatory incentives. In interviews with managers of German EMAS organizations, Neugebauer (2012) reports that the main reasons for participation are firm reputation, precautions regarding regulatory inspections or stakeholder demands. In an OECD survey covering German manufacturing firms in EMAS, Frondel et al. (2004) report ensuring regulatory compliance as the main reason for adoption, partly owing to the principle of strict liability in Germany. Other important motives are the firm reputation, incident prevention and cost-savings due to improved resource efficiency. Bracke et al. (2008) investigate the role of financial characteristics for EMAS participation among European firms and find that the program mainly attracts large firms with a sound financial structure and above

\footnotetext{
${ }^{3}$ Empirical investigations of stock market reactions to other voluntary environmental actions by firms do not show a clearly positive picture (Fisher-Vanden and Thorburn, 2011, Ziegler et al. 2011) which is why shareholder wealth maximization may not necessarily be a prime reason for EMAS participation.
} 
average labor costs. This is in line with the Frondel et al. (2004) and the summary statistics of our sample (see Section 3). ${ }^{4}$

In an own survey of 140 EMAS firms in the German manufacturing sector we asked for their main reasons to participate (Kube and Capellen, 2017). The most frequently stated answers are corporate identity and a credible certification of pro-environmental efforts, optimized documentation, expectations from business customers, regulatory compliance, workplace safety and government incentives. As in Frondel et al. (2004), the initiative for participation often came from internal stakeholders, foremost the corporate management.

EMAS participation is currently incentivized via regulatory facilitations. In fact, German participants face less documentation effort and fewer inspections, e.g. regarding wastewater and recycling (WHG, BImSchG, KrWG). Since 2012, energy intensive firms applying for an exemption from the renewable energy surcharge on electricity prices (EEG) additionally require EMAS or alternative certifications of their energy management systems. Similar rules have been introduced regarding the reduced electricity tax rate in 2013 (EnergieStG), and EMAS participants are exempt from energy audits that are mandatory for large firms since 2015.

In the next Section, we present our data and discuss our empirical strategy to evaluate the impact of EMAS on manufacturing firms' environmental performance.

\section{3) Materials and method}

\subsection{Data}

Various datasets are combined for our analysis. First, from the official EMAS Register lists we collect all certified plants as of March 2016 in different manufacturing sectors (see Appendix A). We obtain the respective firms' trade register numbers from the Hoppenstedt Firm Information Database and VAT numbers from company websites in order to append EMAS participation status to our main dataset: the German production census data AFiD (Amtliche Firmendaten für Deutschland - Official firm data for Germany) provided by the Research Data Centre of the Federal Statistical Office and Statistical Offices of the Länder. This highly reliable dataset is confidential and thus only accessible to approved researchers for scientific purposes. It has been utilized for previous studies on the effects of energy and climate policy (e.g. Löschel et al., 2018, Lutz, 2016, Petrick and Wagner, 2014). Our firm panel covers the years 1995-2014 and comes in a modular structure as follows:

The AFiD-Panel Industrial Units is built upon the German Production Census, the Monthly Report on Plant Operation and the Investment Census. Participation is mandatory for all plants within manufacturing firms that have at least 20 employees. From the plant-level panel we obtain economic variables such as the number of Employees (our proxy of firm size), Revenue (in 1000€) and Gross Output (in 1000€). We define Export Ratio as the value of exports divided by the value of total revenue. Further, a dummy (Multi-plant firm) distinguishes firms consisting of more than one plant.

Appended at the plant-level, the AFiD-Module Use of Energy provides consumption data (in $\mathrm{kWh}$ ) for electricity and 14 different fuel types, e.g. natural gas, coal and oil products. Thus we obtain the total Energy Consumption (in MWh) and we define Energy Intensity as the total Energy Consumption (MWh)

\footnotetext{
${ }^{4}$ Even in the U.S., Videras and Alberini (2000) find that large firms are systematically more likely to join different EPA voluntary programs (Green Lights, WasteWi\$e and 33/50), regardless of program requirements and pollutants covered, presumably due to receiving more attention from consumers and regulators.
} 
per Gross Output (in 1000€). As in Löschel et al. (2018), the fuel-specific data allows us to estimate direct $\mathrm{CO}_{2}$ Emissions of the firm (see Appendix B). We define $\mathrm{CO}_{2}$ Intensity as respective $\mathrm{CO}_{2}$ Emissions (in tons) per Gross Output (in 1000€). Further, we use a dummy (Fossil) to indicate firms that generate own electricity from fossil fuels or fuel switching options (i.e. firms using fossil fuels apart from natural gas and oil for heating purposes, but rather also coal, lignite or process gas and others).

Available since the year 2003, the AFiD-Module Environmental Protection Investments comprises the value of investments into the protection of the environment (Air, Water, Waste, Noise, Nature \& Landscape, Soil, and Noise) and climate (Energy Efficiency, Greenhouse Gas Mitigation, Renewable Energy). This way we use dummies to indicate firms using renewable energy (Renewables), e.g. by solar, wind and hydropower, as well as firms that made any investment into the protection of the environment and climate (Eco-Investments).

From the EMAS Register as of March 2016 we obtain a sample of 423 plants within 271 firms with at least 20 employees operating within selected industries of the German manufacturing sector that were certified between 1995 and 2013 (see Appendix A). Out of these, we could identify 208 firms within the AFiD data. We aggregate the plant data to the firm level to account for potential spillover effects and specific internal accounting methods. Hence, a firm is coded as newly EMAS certified in the year that a firm's first plant enters the EMAS Register. Furthermore, a firm is coded as EMAS certified even if just one of its plants are certified. ${ }^{5}$

All monetary variables are deflated to 2010 levels for each 2-digit level industry via the index of producer prices for industrial products on industry. ${ }^{6}$

We reduce the dataset to sectors with our EMAS participants and exclude outliers, i.e. observations where values of $\mathrm{CO}_{2}$ intensity or energy intensity are above the respective 99th percentile.

\subsection{Descriptive statistics}

In Table 1, we show the number of newly certified firms over years that could be identified in our AFiD panel dataset. The program quickly attracted firms initially, but certification rates have slowed down since the year 2000. Presumably owing to government incentives for large energy consuming firms (as discussed in the previous Section), the rates increased again after 2010. The majority of certified firms operate in the industries fabricated metals, chemicals, machinery, rubber and plastic, and automotive.

In Table 2, we display the summary statistics for the years 2000 and 2010 by certification status. A key insight is that, especially in its first years, the program was able to attract policy relevant firms, i.e. large, energy and emission intensive firms with more revenue and exports than the average firm. Participants are often multinational firms with multiple plants and already invest into the protection of the environment and climate. They are also more likely to have own electricity generation capacities and/or use fossil fuels (such as coal, lignite or liquefied natural gas). Next, we describe our empirical strategy.

\footnotetext{
${ }^{5}$ We merge the EMAS register to the census data based on a firm identifier. This makes it impossible to conduct the analysis at the plant level. However, the majority of the firms in our sample are single-plant firms and we carry out the analysis for these firms alone in our robustness checks.

${ }^{6}$ The price indices data is available on the website of the Federal Statistical Office:

https://www-genesis.destatis.de/genesis/online (Producer Price Index 61241-0003). From 2009 onwards, the industry classification of the dataset is based on NACE rev. 2. In earlier years, the dataset is based on NACE rev 1.1 which we manually transfer to NACE rev. 2 via four-digit industry codes and the official reclassification guide of the German statistical offices.
} 
Table 1: Number of firms by EMAS certification status across 2-digit industries in selected years.

\begin{tabular}{|c|c|c|c|c|c|c|c|c|c|c|}
\hline \multirow[b]{2}{*}{ Industry (NACE classification) } & \multirow[b]{2}{*}{ I } & \multirow[b]{2}{*}{ Year } & \multicolumn{4}{|c|}{ Non-certified firms } & \multicolumn{4}{|c|}{ EMAS certified firms } \\
\hline & & & 2000 & 2005 & 2010 & 2013 & 2000 & 2005 & 2010 & 2013 \\
\hline \multicolumn{3}{|l|}{ 17) Paper and paper products } & 785 & 740 & 707 & 679 & 4 & 5 & 6 & 10 \\
\hline \multicolumn{3}{|c|}{ 20) Chemicals and chemical products } & 924 & 988 & 994 & 1,053 & 19 & 31 & 35 & 41 \\
\hline \multicolumn{3}{|l|}{ 21) Pharmaceutical products } & 227 & 228 & 221 & 237 & 5 & 5 & 6 & 5 \\
\hline \multicolumn{3}{|l|}{ 22) Rubber and plastic products } & 2,634 & 2,561 & 2,591 & 2,698 & 10 & 13 & 19 & 25 \\
\hline \multicolumn{3}{|c|}{ 23) Other nonmetallic mineral products } & 1,812 & 1,446 & 1,330 & 1,363 & 3 & 3 & 5 & 5 \\
\hline \multicolumn{3}{|l|}{ 24) Basic metals } & 866 & 820 & 822 & 818 & 6 & 6 & 9 & 12 \\
\hline \multicolumn{3}{|l|}{ 25) Fabricated metal products } & 6,151 & 5,889 & 6,299 & 6,669 & 23 & 34 & 48 & 57 \\
\hline \multicolumn{3}{|c|}{ 28) Machinery and equipment n.e.c. } & 5,214 & 4,915 & 4,955 & 5,154 & 15 & 21 & 28 & 33 \\
\hline \multicolumn{3}{|l|}{ 29) Motor vehicles and trailers } & 968 & 982 & 970 & 956 & 8 & 12 & 16 & 20 \\
\hline Total & & & 19,581 & 18,569 & 18,889 & 19,627 & 93 & 130 & 172 & 208 \\
\hline
\end{tabular}

Note: (Source: Research Data Centre of the Federal Statistical Office and Statistical Offices of the Länder, Official Firm Data for Germany (AFiD) - AFiD-Panel Industrial Units, AFiD Module Use of Energy, AFiD Module Environmental Protection Investments, survey years 1995-2014, own calculations).

Table 2: Summary Statistics for firms by EMAS certification status in the respective years 2000 and 2010.

\begin{tabular}{|c|c|c|c|c|c|c|c|c|}
\hline \multirow[b]{3}{*}{ Covariate } & \multicolumn{4}{|c|}{ Year 2000} & \multicolumn{4}{|c|}{ Year 2010} \\
\hline & \multicolumn{2}{|c|}{ Certified } & \multicolumn{2}{|c|}{ Non-certified } & \multicolumn{2}{|c|}{ Certified } & \multicolumn{2}{|c|}{ Non-certified } \\
\hline & Mean & Median & Mean & Median & Mean & Median & Mean & Median \\
\hline Energy Consumption (MWh) & 40,803 & 12,285 & 6,045 & 949 & 38,313 & 13,822 & 7,112 & 1,278 \\
\hline Energy Intensity (MWh/1000€) & 0.46 & 0.24 & 0.32 & 0.14 & 0.49 & 0.27 & 0.35 & 0.18 \\
\hline $\mathrm{CO}_{2}$ Emissions $(\mathrm{t})$ & 24,544 & 8,583 & 3,563 & 436 & 24,462 & 6,113 & 3,981 & 538 \\
\hline $\mathrm{CO}_{2}$ Intensity $(\mathrm{t} / 1000 €)$ & 0.23 & 0.13 & 0.13 & 0.07 & 0.22 & 0.15 & 0.14 & 0.08 \\
\hline Employees (Firm size) & 8,436 & 3,400 & 1,602 & 671 & 5868 & 2,404 & 1,547 & 694 \\
\hline Revenue (1000 €) & 141,160 & 59,313 & 24,779 & 7,423 & 112,566 & 40,326 & 27,418 & 7,775 \\
\hline Export Ratio (\%) & 0.30 & 0.26 & 0.19 & 0.09 & 0.32 & 0.28 & 0.24 & 0.16 \\
\hline Renewables (dummy) & - & & - & & 0.10 & 0.00 & 0.05 & 0.00 \\
\hline Fossil (dummy) & 0.10 & 0.00 & 0.03 & 0.00 & 0.17 & 0.00 & 0.08 & 0.00 \\
\hline Eco-Investments (dummy) & - & & - & & 0.22 & 0.00 & 0.12 & 0.00 \\
\hline Multi-plant firm (dummy) & 0.25 & 0.00 & 0.09 & 0.00 & 0.41 & 0.00 & 0.09 & 0.00 \\
\hline Nr. of observations & \multicolumn{2}{|c|}{93} & \multicolumn{2}{|c|}{19,581} & \multicolumn{2}{|c|}{172} & \multicolumn{2}{|c|}{18,889} \\
\hline
\end{tabular}

Note: Covariates Renewables and Eco-investments are only available since the year 2003 (Source: Research Data Centre of the Federal Statistical Office and Statistical Offices of the Länder, Official Firm Data for Germany (AFiD) - AFiD-Panel Industrial Units, AFiD Module Use of Energy, AFiD Module Environmental Protection Investments, survey years 1995-2014, own calculations).

\subsection{Empirical strategy}

Formally, we are interested in the Average Treatment Effect on the Treated (ATT), which we infer by using non-certified firms as counterfactual observations for EMAS participants. However, as firms voluntarily adopt EMAS we have to deal with the problem of self-selection (Heckman, 1979).

In previous evaluations of voluntary programs, the favored identification strategy is an instrumental variable (IV) approach, such as in Anton et al. (2004), Arimura et al. (2008), Arora and Cason (1996), Barla (2007), Bui and Kapon (2012), Carrión-Flores et al. (2013), Khanna and Damon (1999), Nishitani (2011), or Vidovic and Khanna (2007). Popular instruments are governmental encouragement to 
program participation, prior participation in other environmental programs, or the frequency of inspections and fines. However, the extent to which such instruments are truly exogenous will vary from case to case. In our study, variables that could serve as instruments are not available. Prior certification in other programs such as ISO14001, could certainly exert explanatory power for EMAS participation, but it would be hard to argue that there were no direct effects from prior programs on the outcome variables, i.e. $\mathrm{CO}_{2}$ and energy intensity. There is also no official ISO14001 register for Germany.

For these reasons, our empirical strategy is a pre-processing of the dataset (Ho et al., 2007) via the Coarsened Exact Matching (CEM) approach proposed by lacus et al. $(2011,2012)$, before running a Difference-in-Differences regression. The CEM algorithm stratifies matching covariates - binary or continuous - into bins, and each participant is matched to all observations that are in exactly the same bins for all matching covariates. Its non-parametric nature accounts for higher moments of covariates and reduces model dependence. By definition, it yields strong balance in covariates and lower root mean square error than existing approaches, such as Propensity Score Matching or Nearest-Neighbor Matching (lacus, 2011, 2012). CEM has been successfully applied in previous studies, e.g. on the effectiveness of energy audits (Schleich and Fleiter, 2017) or spillover effects from municipal greenbuilding procurement (Simcoe and Toffel, 2014). In the program evaluation literature, the MatchingDifference-in-Differences approach has in general become well established and is used in studies such as Blackman et al. (2010), Fowlie et al. (2012), or Löschel et al. (2018).

Once certified, firms generally remain in the program, which is in favor of our matching approach modeling participation as a one-time decision. The identifying assumption is that conditional on the matching covariates, the firm's decision to participate in EMAS is as good as random. Inferring the average treatment effect on the treated (ATT) via Difference-in-Differences "... permits selection to be based on potential program outcomes and allows for selection on unobservables." (Heckman et al., 1997). It is valid under the assumption that outcome trends would be equal for both groups in the absence of participation in the program. We test this assumption by assessing the changes in $\mathrm{CO}_{2}$ intensity from four and three years prior to certification, in years most likely prior to the participation decision. Overall, these are not different across certification status groups (see Appendix C), which is in favor of our approach.

\section{Matching covariates}

We match firms newly certified with EMAS in a given year to firms that are not certified in the same year. The matching algorithm is based on a vector of lagged firm-specific characteristics from precertification periods, of which some proxy the firm's "greenness". The average duration from the decision to participate until certification takes place, is 15 months and less than 24 months for almost all respondents in a government survey (Federal Environment Agency, 2013). ${ }^{7}$ Thus we use covariate values from three years prior to certification that are, most likely, exogenous to the participation decision. Our approach is related to Brand and Xie (2007) and illustrated in Figure 1. If a firm is certified in an arbitrary year $t_{4}$ then we assume it decided to participate in year $t_{2}$ and match based on covariate values from year $t_{1}$.

\footnotetext{
${ }^{7}$ Alternatively, we could use the covariate average over more previous years, but this would critically reduce our sample size and also not account for most recent dynamics of the firms.
} 
Figure 1: Illustration of the dynamic matching structure for firms certified in arbitrarily chosen period $t_{4}$.

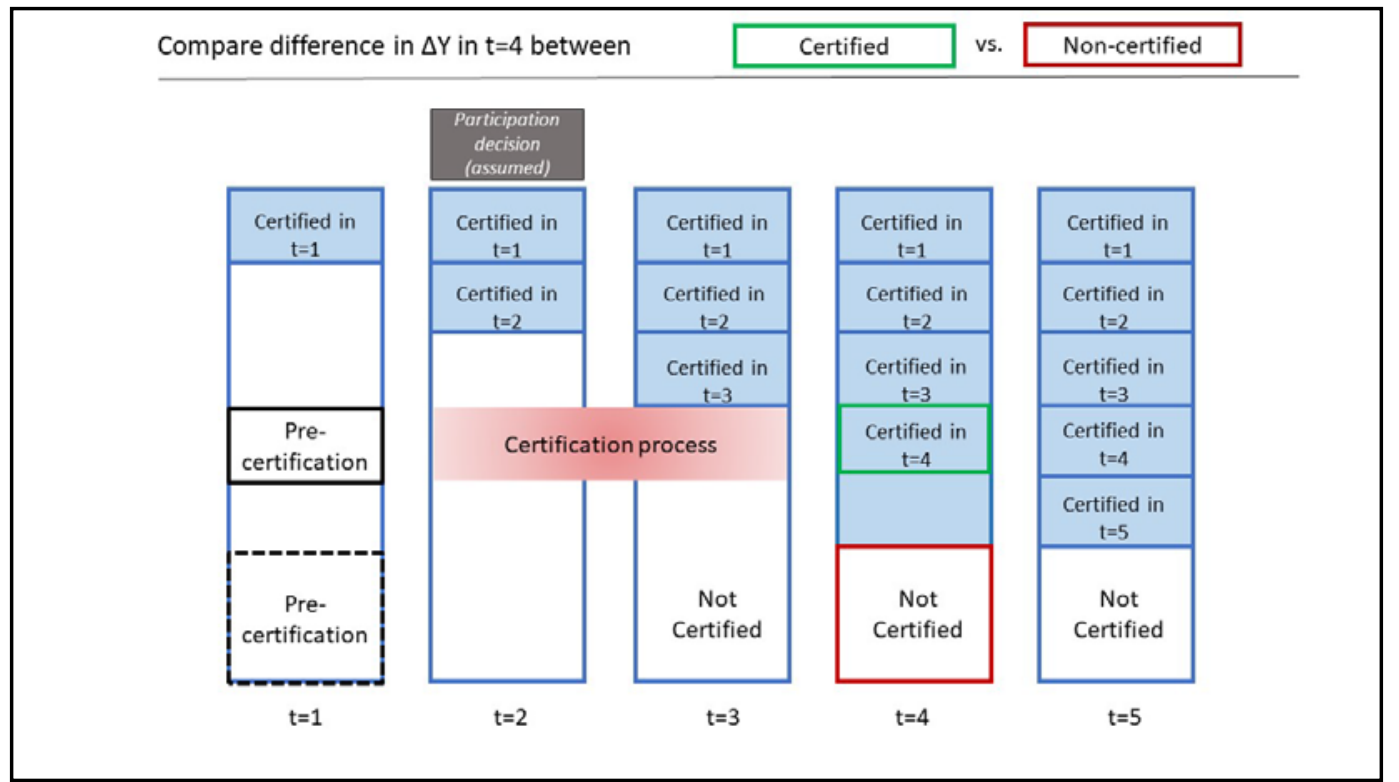

Note: (Source: own illustration based on Brand and Xie (2007)).

We select the matching covariates that have been shown as most relevant in the previously discussed literature and our own pre-study survey (Kube and Capellen, 2017).

First, we include the log of Energy Consumption and the $\mathrm{CO}_{2}$ Intensity as determinants of the environmental impact and costs associated with resource usage. ${ }^{8}$

Financial capabilities to install and maintain a certified environmental management system are proxied via Revenue. We also include the share of revenue from exports (Export Ratio), as Richter and Schiersch (2017) show that a higher export intensity is associated with significantly lower emissions intensity for German manufacturing firms. A global market scope may also come along with additional pressure from international stakeholders to manage environmental impacts and certify a sustainable production (Khanna and Anton, 2002).

Environmental management systems may also be more attractive for firms with own electricity generation and with an option for fuel switching decisions, which we indicate with a dummy (Fossil). From 2003 onwards, we proxy awareness regarding low-carbon alternatives and pro-environmental attitudes of the firm via dummies that indicate usage of renewable energy (Renewables) and investments into the protection of the environment and climate (Eco-Investments).

\section{Outcome estimation}

Based on the matched sample we assess the program's impact on firms' environmental performance by comparing the changes in outcomes across participant status. Although EMAS addresses various environmental externalities, we focus on $\mathrm{CO}_{2}$ and energy intensity, and further assess the usage of renewable energy and investments into the protection of the environment and climate. Formally, we estimate the Difference-in-Differences of outcomes (Heckman et al., 1997, 1998) via the following regression:

\footnotetext{
${ }^{8}$ Although this implies a double-counting of intermediate goods, we prefer gross output over value added since gross output better reflects disembodied technological change and does not assume separability between intermediate goods and value added. At last, the dataset only provides value added data for a subset of firms with more than 500 employees, which would drastically reduce the number of observations for our purpose.
} 
where $\Delta Y_{i s t *}$ is the change in outcomes (e.g. $\mathrm{CO}_{2}$ intensity) of firm $i$ in industry $s$ from certification year $t$ towards a certain pre- or post-certification year $t^{*}$. We estimate effects starting from two years prior to certification until four years post certification, because firms will exert effort to assure a certification and because participation may require time and experience to translate into improvements. We also investigate the change from four and three years prior to certification in order to test the validity of the Difference-in-Differences estimation, which depends upon the common trend assumption.

The dummy $E M A S_{i s t}$ is equal to one if the firm was EMAS certified in year $t$. The $E E G_{i s t}$, dummy is equal to one if the firm was eligible for exemptions from the renewable energy surcharge at year $t^{\prime}$, which is three years prior to certification year $t .{ }^{9}$ This way we control for the possibility that eligibility may have encouraged EMAS certification and further incentives for energy saving behavior, or in the case of the EEG exemption, the reverse (Gerster, 2017). We also include the vector of lagged matching covariates $\boldsymbol{X}_{\boldsymbol{i s t}}$, to control for remaining variation despite matching. In order to account for industry heterogeneity we only match firms in the same 2-digit industry. We further include year-dummies $\tau_{t}$ and state-dummies $\mu_{c}$. Standard errors $\varepsilon_{i s t}$ are i.i.d.

In our baseline analysis, we exclude multi-plant firms because EMAS certification of a plant may exert less precisely estimable effects in firms with multiple plants, where not necessarily all plants are certified. One of our robustness checks in Section 5 is to run the CEM regressions also including multiplant firms. Owing to a structural change in the energy statistics in 2003, we split the sample and estimate the models using two sub-samples: years 1995-2002 and years 2003-2014. Accordingly we only estimate the effect for firms that were certified in years 1996-2002 and 2003-2013 respectively. ${ }^{10}$ Another challenge to our analysis is the fact that the EMAS Register only lists currently registered organizations, i.e. that we cannot observe firms that left the program before 2016. In a phone interview with the German EMAS Register Helpdesk (as of March 2016), we were assured that dropout numbers are especially low among manufacturing firms. ${ }^{11}$ Still, this issue may affect the Stable Unit Treatment Value Assumption (SUTVA) if EMAS dropouts are by chance matched as control units. However, we minimize this potential risk by including a large number of control units, also in the CEMmatched sample.

In Table 3, we display the number of observations available for the regressions, i.e. observations with lagged covariate values, separately for newly certified firms and non-certified firms in the respective sub-periods. In the first sub-period, there are 67 EMAS certified firms with lagged covariate values. Out of these, CEM could match 64 to 7,960 control firms. In the second sub-period, there are 49 newly certified firms with lagged covariate values. Out of these, 46 could be matched to 5,533 control firms.

\footnotetext{
${ }^{9}$ Since 2008, energy intensive firms (energy consumption $>10 \mathrm{GWh} / \mathrm{a}$ ) that are eligible for an exemption also require an energy management system certification like EMAS, ISO14001, ISO16001, or a comparable certification by an external auditor (EEG 2009). Since 2012, only EMAS or ISO50001 are accepted certifications (EEG 2012). However, among the firms that were EMAS certified between 2008 and 2013, only nine firms are on the list of firms exempt from the surcharge between 2010 and 2013. Similarly, since 2013 energy intensive manufacturing firms applying for a reduced electricity tax rate also require EMAS or a comparable energy management system certification such as ISO50001. However, all new EMAS participants from 2013 onwards in our dataset exceed the threshold electricity consumption.

${ }^{10}$ Matching firms on lagged covariates forces us to drop plants that joined in 1995, losing four participant observations. However, we do not drop firms that joined in 1996 and 1997, where we only have a one-year and two-year lag available because of the program's rapid introduction, which lowers the risk of firms changing their behavior in anticipation of the program. We also leave out firms certified in 2014 since we cannot estimate postcertification effects for these participants.

${ }^{11}$ In phone interviews with EMAS auditors (as of February 2018), we were assured that firms mainly decided to leave EMAS due to its running costs, not because of new requirements following the revisions in 2001 and 2010.
} 
Owing to the large number of control units, we are confident that EMAS dropouts do not hamper our analysis. In the last two columns the same figures are shown for the subsample of a robustness check where we do not exclude multi-plant firms (see Section 5).

Table 3: Number of observations with lagged covariate values per sub-period in the full sample and CEM matched sample, over all sectors, both excluding and including multi-plant firms.

\begin{tabular}{|c|rrrr|}
\hline & \multicolumn{2}{|c|}{ Excluding multi-plant firms } & \multicolumn{2}{c|}{ Including multi-plant firms } \\
\hline Sub-period & $\mathbf{1 9 9 5 - 2 0 0 2}$ & $\mathbf{2 0 0 3 - 2 0 1 4}$ & $\mathbf{1 9 9 5 - 2 0 0 2}$ & 88 \\
\hline Newly certified firms & 67 & 49 & 60 \\
Matched: & 64 & 46 & 65 \\
\hline Non-certified firms & 98,942 & 161,217 & 109,128 \\
Matched: & 7,960 & 5,533 & 10,177 \\
\hline
\end{tabular}

Note: (Source: Research Data Centre of the Federal Statistical Office and Statistical Offices of the Länder, Official Firm Data for Germany (AFiD) - AFiD-Panel Industrial Units, AFiD Module Use of Energy, AFiD Module Environmental Protection Investments, survey years 1995-2014, own calculations).

Given these data limitations and the missing information on certification according to ISO14001 our findings should conservatively be interpreted as the net effect of adopting EMAS beyond any such proenvironmental efforts of the firms that we cannot observe.

\section{4) Main results and discussion}

We now turn to the regressions of our main outcomes within the preferred CEM-matched sample of single-plant firms only (Table 4). For brevity, we only report the EMAS coefficients as well as the respective standard errors and $p$-values of each regression.

\section{$\mathrm{CO}_{2}$ intensity}

The first two outcome columns in Table 4 show estimates of the average difference in the change of $\log \mathrm{CO}_{2}$ intensity across participation status (Difference-in-Differences) over certain years before/after certification. Results are shown in separate columns for each sub-period. The first row ("2 Y prior") reports the change from two years prior to certification to the year of certification, accounting for effort shortly after deciding to join EMAS. In the next row ("1 Y prior"), we measure the difference from one year prior to certification towards the year of certification. All further rows ("1 Y post" until " 4 Y post") below show the change from the year of certification to up to four years after certification. Owing to the large number of regressions, we only report the coefficient and respective significance levels.

First, the CEM estimates generally show no significant effect of EMAS on participants' $\mathrm{CO}_{2}$ intensity in either direction, and this finding is robust across periods. If they were significant, the point estimates would suggest a change in $\mathrm{CO}_{2}$ intensity of less than ten percent.

\section{Energy intensity}

Next, we assess whether participation had an effect on the energy intensity of production, i.e. energy consumption per unit of gross output. If this is the case, then potential improvements may just not have translated into a lower $\mathrm{CO}_{2}$ intensity for other reasons, such as changes in the fuel mix.

However, the point estimates also suggest no significant impact of EMAS on firms' energy intensity and closely resemble the findings for $\mathrm{CO}_{2}$ intensity. 
Table 4: Main outcomes for the CEM matched sample, excluding multi-plant firms.

\begin{tabular}{|c|c|c|c|c|c|c|}
\hline \multirow{2}{*}{$\begin{array}{l}\text { Dep. Var. } \\
\text { Sub-period }\end{array}$} & \multicolumn{2}{|c|}{ Log $\mathrm{CO}_{2}$ Intensity } & \multicolumn{2}{|c|}{ Log Energy Intensity } & \multirow{2}{*}{$\begin{array}{l}\text { Renewables } \\
2003-2014\end{array}$} & \multirow{2}{*}{$\begin{array}{c}\text { Eco- } \\
\text { Investments } \\
2003-2014\end{array}$} \\
\hline & $1995-2002$ & 2003-2014 & 1995-2002 & 2003-2014 & & \\
\hline \multirow[t]{2}{*}{$2 Y$ prior } & 0.045 & -0.009 & 0.071 & 0.019 & -4 & 13 \\
\hline & $(0.081)$ & $(0.061)$ & $(0.092)$ & $(0.066)$ & (76) & (24) \\
\hline \multirow[t]{2}{*}{$1 Y$ prior } & -0.022 & 0.044 & 0.000 & 0.055 & -- & -- \\
\hline & $(0.061)$ & (0.110) & $(0.070)$ & (0.111) & & \\
\hline \multirow[t]{2}{*}{$1 Y$ post } & -0.005 & -0.031 & -0.008 & -0.014 & 20 & -32 \\
\hline & (0.039) & (0.041) & $(0.046)$ & $(0.046)$ & (21) & (30) \\
\hline \multirow[t]{2}{*}{$2 Y$ post } & 0.044 & 0.008 & 0.036 & 0.010 & -- & -- \\
\hline & $(0.049)$ & $(0.077)$ & $(0.056)$ & $(0.080)$ & & \\
\hline \multirow[t]{2}{*}{3 Y post } & 0.070 & 0.018 & 0.084 & 0.024 & -- & -- \\
\hline & $(0.057)$ & $(0.067)$ & $(0.065)$ & $(0.073)$ & & \\
\hline \multirow[t]{2}{*}{$4 Y$ post } & 0.025 & 0.082 & 0.040 & 0.112 & -215 & -23 \\
\hline & $(0.080)$ & $(0.068)$ & (0.089) & $(0.073)$ & $(1112)$ & (46) \\
\hline
\end{tabular}

Note: Dependent variables are the change in log $\mathrm{CO}_{2}$ intensity and log energy intensity, as well as the usage of renewables (in MWh, aggregated over 3 years), and the investments into the protection of the environment and climate (in 1000€, aggregated over 3 years). The latter two outcome variables are only available since the year 2003 and results only shown for selected years due to the pre-and post-certification clustering. Standard errors are i.i.d. and shown in parentheses. $P$ values: *: $p<0.1,{ }^{* *}: p<0.05, * * *: p<0.01$ (Source: Research Data Centre of the Federal Statistical Office and Statistical Offices of the Länder, Official Firm Data for Germany (AFiD) - AFiD-Panel Industrial Units, AFiD Module Use of Energy, AFiD Module Environmental Protection Investments, survey years 1995-2014, own calculations).

\section{Renewable energy consumption}

As another channel for environmental improvements, we assess whether EMAS led to an increasing use of renewable energy sources. We measure this outcome by aggregating the renewable energy usage in $\mathrm{MWh}$ (power and other renewable sources) over three years from different starting years onwards. That is, in the first row ("2 Y prior") we measure the aggregate renewable energy usage in the two years prior to certification and the year of certification, and then estimate the average difference across participation status. Likewise the post-certification estimation " 1 Y post" comprises the difference in aggregate renewable consumption in the first three years post certification, and " $4 \mathrm{Y}$ post" considers the years 4-6 following certification. ${ }^{12}$ This way we separate pre- and post-certification outcomes. Owing to data availability, we can only analyze the sub-period 2003-2014. In general, we cannot conclude that EMAS certified firms increase their renewable consumption relative non-certified peers.

\section{Investments into the protection of the environment and climate}

Our last outcome variable concerns investments into the protection of the environment and climate. It comprises various measures to e.g. reduce air and water pollution or waste, as well as investments into energy efficiency. As such, a survey of German manufacturing firms by Löschel et al. (2017) reports a significant correlation between energy management practices and investments into energy saving technologies. Analogously to renewable energy consumption, we add up total investments (in 1000€) over three years beginning at different starting years. ${ }^{13}$ The variable is also only available from 2003

\footnotetext{
${ }^{12}$ An alternative measuring via the share of energy from renewables was problematic due to many observations with a share of zero.

${ }^{13}$ As for renewables, relating the investment value to revenue would impede measuring changes due to zero values.
} 
onwards. Again, we find no evidence of EMAS participation leading to an increasing investment activity.

\section{5) Robustness checks}

In order to assess the robustness of our findings, we complement our CEM-matched sample regression of single-plant firms with different specifications. ${ }^{14}$

First, we run the regression of the CEM matched sample again but now do not exclude multi-plant firms anymore. In the first sub-period this yields 88 firms newly certified with EMAS. Out of these, 85 were matched via the CEM algorithm to 10,177 control firms (see Table 3). In the second sub-period, there are 60 EMAS firms and all could be matched to 6,343 control firms.

Second, we run an OLS regression on the full sample (excluding multi-plant firms) where we simply include the lagged covariates $\boldsymbol{X}_{\text {ist }}$, from the CEM as controls:

$$
\Delta Y_{i s t *}=\alpha+\beta \cdot E M A S_{i s t}+\varnothing E E G_{i s t \prime}+\gamma \cdot \boldsymbol{X}_{i s t^{\prime}}+\tau_{t}+\mu_{c}+\sigma_{s}+\varepsilon_{i s t} .
$$

Note that instead of exact matching within the same 2-digit industry we now include 2-digit industrydummies $\sigma_{s}$

At last, we run the OLS regression again but now also include the Propensity Score $P S_{\text {ist }}$, as a covariate, following the methodology of Brouhle et al. $(2009,2010)$ and Khanna and Damon (1999):

$\Delta Y_{i s t *}=\alpha+\beta \cdot E M A S_{i s t}+\varnothing E E G_{i s t}+\gamma \cdot \boldsymbol{X}_{i s t^{\prime}}+\tau_{t}+\mu_{c}+\sigma_{s}+P S_{i s t^{\prime}}+\varepsilon_{i s t}$.

Therefore, we estimate the Propensity Score of participation based on the lagged covariates (as for the CEM matching) via a logit model (see Appendix D). Note that all single-plant observations with lagged covariate values are used in these OLS robustness checks.

When we include multi-plant firms in the CEM matched sample regression (Table 5), the estimates mostly resemble findings from our preferred specification (Table 4). Nonetheless, the results suggest that firms increase their emissions intensity and energy intensity by about ten percent and more in the long run, both in the early and late sub-period, at a significance level of five percent. This result would question the program effectiveness, but it is not robust over varying years since certification and vanishes when we focus on single-plant firms. Results are robust for renewable usage and investments into the protection of the environment and climate.

Estimates in the OLS regression (Table 6) and the OLS regression including the Propensity Score (Table 7) are in line with the main regressions addressing the self-selection problem via a CEM-matched sample (both Table 4 and 5). If they were significant, point estimates for $\mathrm{CO}_{2}$ intensity and energy intensity would mostly suggest only minor changes shortly around certification, and increases by at least eight percent in the long run. Results for the two additional outcome variables (Renewables and Eco-Investments) are still insignificant, but the point estimates are somewhat larger than in the CEM matched sample regression.

\footnotetext{
${ }^{14}$ In an earlier version, we also ran regressions for the 2-digit industry with the largest number of participants (Fabricated metal products). Results were, however, not significant for our main outcomes, which is why we did not include this test in the final version of the paper.
} 
In general, the robustness checks are in line with the results of our preferred specification, where we cannot detect a substantial impact of EMAS certification on any of the four outcome variables.

Table 5: Robustness check within the CEM sample matched - this time not excluding multi-plant firms.

\begin{tabular}{|c|c|c|c|c|c|c|}
\hline \multirow{2}{*}{$\begin{array}{l}\text { Dep. Var. } \\
\text { Sub-period }\end{array}$} & \multicolumn{2}{|c|}{ Log $\mathrm{CO}_{2}$ Intensity } & \multicolumn{2}{|c|}{ Log Energy Intensity } & \multirow{2}{*}{$\begin{array}{c}\text { Renewables } \\
2003-2014\end{array}$} & \multirow{2}{*}{$\begin{array}{c}\begin{array}{c}\text { Eco- } \\
\text { Investments }\end{array} \\
2003-2014\end{array}$} \\
\hline & 1995-2002 & 2003-2014 & 1995-2002 & 2003-2014 & & \\
\hline \multirow[t]{2}{*}{$2 Y$ prior } & -0.007 & -0.015 & -0.003 & 0.044 & -20 & 51 \\
\hline & $(0.057)$ & $(0.053)$ & (0.064) & $(0.056)$ & (146) & (35) \\
\hline \multirow[t]{2}{*}{$1 Y$ prior } & -0.043 & 0.040 & -0.015 & 0.060 & -- & -- \\
\hline & $(0.040)$ & $(0.088)$ & $(0.045)$ & (0.090) & & \\
\hline \multirow[t]{2}{*}{$1 Y$ post } & -0.005 & -0.025 & -0.017 & -0.008 & 15 & 19 \\
\hline & $(0.032)$ & $(0.039)$ & $(0.038)$ & (0.041) & (126) & (39) \\
\hline \multirow[t]{2}{*}{2 Y post } & 0.050 & 0.039 & 0.035 & 0.048 & -- & -- \\
\hline & (0.041) & $(0.064)$ & $(0.046)$ & $(0.063)$ & & \\
\hline \multirow[t]{2}{*}{$3 Y$ post } & $0.108^{* *}$ & 0.067 & $0.095^{*}$ & 0.076 & -- & - \\
\hline & $(0.050)$ & (0.063) & $(0.057)$ & $(0.066)$ & & \\
\hline \multirow[t]{2}{*}{4 Y post } & 0.061 & $0.138^{* *}$ & 0.083 & $0.151^{* *}$ & -153 & -17 \\
\hline & $(0.060)$ & $(0.066)$ & $(0.068)$ & $(0.068)$ & (772) & (83) \\
\hline
\end{tabular}

Note: Dependent variables are the change in log $\mathrm{CO}_{2}$ intensity and log energy intensity, as well as the usage of renewables (in MWh, aggregated over 3 years), and the investments into the protection of the environment and climate (in $1000 €$, aggregated over 3 years). The latter two outcome variables are only available since the year 2003 and results only shown for selected years due to the pre-and post-certification clustering. Standard errors are i.i.d. and shown in parentheses. $P$ values: *: $p<0.1, * *: p<0.05,{ }^{* *}: p<0.01$ (Source: Research Data Centre of the Federal Statistical Office and Statistical Offices of the Länder, Official Firm Data for Germany (AFiD) - AFiD-Panel Industrial Units, AFiD Module Use of Energy, AFiD Module Environmental Protection Investments, survey years 1995-2014, own calculations).

Table 6: Robustness check using OLS on the full sample excluding multi-plant firms.

\begin{tabular}{|c|c|c|c|c|c|c|}
\hline \multirow{2}{*}{$\begin{array}{l}\text { Dep. Var. } \\
\text { Sub-period }\end{array}$} & \multicolumn{2}{|c|}{ Log $\mathrm{CO}_{2}$ Intensity } & \multicolumn{2}{|c|}{ Log Energy Intensity } & \multirow{2}{*}{$\begin{array}{c}\text { Renewables } \\
2003-2014\end{array}$} & \multirow{2}{*}{$\begin{array}{c}\begin{array}{c}\text { Eco- } \\
\text { Investments }\end{array} \\
2003-2014\end{array}$} \\
\hline & $1995-2002$ & $2003-2014$ & $1995-2002$ & 2003-2014 & & \\
\hline \multirow[t]{2}{*}{$2 Y$ prior } & 0.013 & -0.008 & 0.016 & 0.044 & -296 & -56 \\
\hline & $(0.077)$ & $(0.070)$ & $(0.084)$ & $(0.076)$ & (536) & (85) \\
\hline \multirow[t]{2}{*}{1 Y prior } & 0.000 & -0.017 & 0.011 & 0.001 & -- & - \\
\hline & $(0.058)$ & (0.059) & $(0.062)$ & $(0.065)$ & & \\
\hline \multirow[t]{2}{*}{$1 Y$ post } & 0.022 & -0.005 & 0.015 & 0.009 & -254 & -107 \\
\hline & $(0.069)$ & (0.055) & $(0.076)$ & $(0.058)$ & (4036) & (106) \\
\hline \multirow[t]{2}{*}{2 Y post } & 0.089 & 0.060 & 0.097 & 0.073 & -- & -- \\
\hline & $(0.086)$ & $(0.067)$ & (0.096) & (0.072) & & \\
\hline \multirow[t]{2}{*}{$3 Y$ post } & 0.141 & 0.091 & 0.148 & 0.107 & -- & -- \\
\hline & $(0.096)$ & $(0.073)$ & (0.107) & $(0.078)$ & & \\
\hline \multirow[t]{2}{*}{4 Y post } & 0.121 & 0.108 & 0.165 & 0.138 & -615 & 228 \\
\hline & $(0.103)$ & $(0.084)$ & $(0.115)$ & (0.089) & (5973) & (162) \\
\hline
\end{tabular}

Note: Dependent variables are the change in $\log \mathrm{CO}_{2}$ intensity and log energy intensity, as well as the usage of renewables (in MWh, aggregated over 3 years), and the investments into the protection of the environment and climate (in 1000€, aggregated over 3 years). The latter two outcome variables are only available since the year 2003 and results only shown for selected years due to the pre-and post-certification clustering. Standard errors are i.i.d. and shown in parentheses. $P$ values: *: $p<0.1,{ }^{* *}: p<0.05,{ }^{* * *}: p<0.01$ (Source: Research Data Centre of the Federal Statistical Office and Statistical Offices of the Länder, Official Firm Data for Germany (AFiD) - AFiD-Panel Industrial Units, AFiD Module Use of Energy, AFiD Module Environmental Protection Investments, survey years 1995-2014, own calculations). 
Table 7: Robustness check using OLS and controlling for the Propensity Score on the full sample excluding multi-plant firms.

\begin{tabular}{|c|c|c|c|c|c|c|}
\hline \multirow{2}{*}{$\begin{array}{l}\text { Dep. Var. } \\
\text { Sub-period }\end{array}$} & \multicolumn{2}{|c|}{ Log $\mathrm{CO}_{2}$ Intensity } & \multicolumn{2}{|c|}{ Log Energy Intensity } & \multirow{2}{*}{$\begin{array}{l}\text { Renewables } \\
2003-2014\end{array}$} & \multirow{2}{*}{$\begin{array}{c}\begin{array}{c}\text { Eco- } \\
\text { Investments }\end{array} \\
2003-2014\end{array}$} \\
\hline & 1995-2002 & 2003-2014 & $1995-2002$ & 2003-2014 & & \\
\hline \multirow[t]{2}{*}{2 Y prior } & 0.020 & -0.009 & 0.038 & 0.025 & -262 & -30 \\
\hline & (0.088) & $(0.080)$ & $(0.096)$ & $(0.086)$ & $(440)$ & (39) \\
\hline \multirow[t]{2}{*}{$1 Y$ prior } & -0.018 & -0.016 & -0.005 & -0.005 & -- & -- \\
\hline & $(0.065)$ & $(0.066)$ & $(0.071)$ & $(0.072)$ & & \\
\hline \multirow[t]{2}{*}{$1 Y$ post } & 0.006 & -0.016 & 0.015 & 0.004 & -163 & -77 \\
\hline & (0.079) & $(0.061)$ & $(0.088)$ & $(0.065)$ & (4904) & (50) \\
\hline \multirow[t]{2}{*}{$2 Y$ post } & 0.091 & 0.063 & 0.120 & 0.080 & -- & -- \\
\hline & $(0.100)$ & $(0.076)$ & (0.111) & $(0.081)$ & & \\
\hline \multirow[t]{2}{*}{$3 Y$ post } & 0.118 & 0.083 & 0.170 & 0.106 & -- & -- \\
\hline & (0.109) & $(0.082)$ & (0.122) & $(0.087)$ & & \\
\hline \multirow[t]{2}{*}{$4 Y$ post } & 0.116 & 0.095 & 0.170 & 0.135 & -525 & -83 \\
\hline & $(0.115)$ & $(0.095)$ & $(0.130)$ & (0.101) & (7153) & (53) \\
\hline
\end{tabular}

Note: Dependent variables are the change in log $\mathrm{CO}_{2}$ intensity and log energy intensity, as well as the usage of renewables (in MWh, aggregated over 3 years), and the investments into the protection of the environment and climate (in 1000€, aggregated over 3 years). The latter two outcome variables are only available since the year 2003 and results only shown for selected years due to the pre-and post-certification clustering. Standard errors are i.i.d. and shown in parentheses. $P$ values: *: $p<0.1,{ }^{* *}: p<0.05,{ }^{* * *}: p<0.01$ (Source: Research Data Centre of the Federal Statistical Office and Statistical Offices of the Länder, Official Firm Data for Germany (AFiD) - AFiD-Panel Industrial Units, AFiD Module Use of Energy, AFiD Module Environmental Protection Investments, survey years 1995-2014, own calculations).

\section{6) Conclusions}

In this paper, we investigate German manufacturing firms that are voluntarily certified with the environmental management system EMAS, and whether these firms show significant changes in their $\mathrm{CO}_{2}$ intensity and energy intensity relative to non-certified peers. Further, we investigate the impact of participation on the usage of renewable energy sources and investments into the protection of the environment and climate. We use the CEM approach to create a matched sample based on lagged covariates and estimate the Difference-in-Differences of outcomes via regression analysis. An assessment of $\mathrm{CO}_{2}$ intensity pre-trends shows no significant difference across participation status, which substantiates the validity of this approach. For robustness, we also run OLS regressions, with and without the Propensity Score for program participation.

We focus on changes in outcomes both before and after certification. However, in general the results are insignificant. It may be the case that a demanding voluntary program like EMAS only leads to small improvements that we cannot detect in our data. Nonetheless, the results raise doubt about the program's effectiveness.

One explanation of our findings could be that participating firms actually detect further options for improvements due to the program, but that these measures are just not profitable under the current situation of low prices for energy and $\mathrm{CO}_{2}$ emissions. In a scenario of rising prices, a scheme like EMAS might thus unfold a stronger lever for environmental policy.

On the other hand, EMAS participants are often large and energy intensive firms, that often have already implemented an energy management system. In that case, an additional EMAS certification may not provide additional improvements or information (European Environment Agency, 2008). As 
such, almost half of EMAS participants are also certified with ISO14001, which in itself demands an environmental management system (Federal Environment Agency, 2013).

Another reason for our findings may be that firms do not mainly improve energy usage and $\mathrm{CO}_{2}$ emissions with EMAS. Instead, they may rather focus their efforts on other externalities such as air, water and land pollution or wastes, which we cannot observe in our dataset. However, we do not observe a significant increase of investments into the protection of the environment and climate or an increased use of renewable energy sources. Future work could involve pollution data to assess this question.

Our findings are in line with the existing literature for other countries in raising doubt about the effectiveness of voluntary measures with respect to greenhouse gas emissions. Although EMAS does not primarily focus on energy and resulting emissions, it is among its key performance indicators and a salient option for action. With its implementation by the European Union, EMAS has the potential to substantiate a strong credibility of efforts. However, it is only one out of many certifications for firms' pro-environmental efforts. Hence, further research on soft instruments is required to gain a more complete picture of the effectiveness of soft regulation.

Finally, future research could investigate measures where firms participate by law, rather than by choice. Potentially, the effects of such policies are stronger as they may address firms with less knowledge about potential measures that ultimately translate into environmental improvements and cost savings. 


\section{Acknowledgements}

We would like to thank Dietrich Earnhart and Ulrich Wagner for excellent comments and the seminar audiences at the Centre for European Economic Research, the University of Münster, the University of Barcelona and the IAEE Groningen 2018. We gratefully acknowledge the Research Data Centre of the Statistical Offices Germany for granting access to the AFiD data, and in particular Stefan Seitz for his support regarding our estimation code. We thank Patrick Capellen for excellent research assistance. This work was supported by the Bundesministerium für Bildung und Forschung (BMBF) [Grant nr. 100303184, Verbundvorhaben ENavi - Energiewende-Navigationssystem zur Erfassung, Analyse und Simulation der systemischen Vernetzungen - Teilvorhaben F0, Kopernikus-Projekt der Energiewende]. 
AG Energiebilanzen: Energiebilanz der Bundesrepublik Deutschland 1995 - 2014, https://agenergiebilanzen.de/7-0-Bilanzen-1990-2016.html [10.01.2019].

Allcott, H., Greenstone, M. (2012): Is there an Energy Efficiency Gap? Journal of Economic Perspectives. 26(1), 3-28.

Anton, W., Deltas, G., Khanna, M. (2004): Incentives for environmental self-regulation and implications for environmental performance. Journal of Environmental Economics and Management, 48, 632-654.

Arimura, T., Hibiki, A., Katayama, H. (2008): Is a voluntary approach an effective environmental policy instrument? A case for environmental management systems. Journal of Environmental Economics and Management, 55, 281-295.

Arimura, T., Darnell, N., Katayama, H. (2011): Is ISO14001 a gateway to more advanced voluntary action? The case of green supply chain management. Journal of Environmental Economics and Management, 61, 170-182.

Arora, S., Cason, T. (1996): Why do firms volunteer to exceed environmental regulation? Understanding participation in EPA's 33/50 program. Land Economics, 72(4), 413-432.

Barla, P. (2007): ISO 14001 certification and environmental performance in Quebec's pulp and paper industry. Journal of Environmental Economics and Management, 53, 291-306.

Blackman, A., Lahiri, B., Pizer, W., Planter, M., Piña, C. (2010): Voluntary environmental regulation in developing countries: Mexico's Clean Industry Program. Journal of Environmental Economics and Management, 60, 182-192.

Bloom, N., Genakos, C., Martin R., Sadun, R. (2010): Modern management: Good for the environment or just hot air? The Economic Journal, 120, 551-572.

Boyd, G., Curtis, E. (2014): Evidence of an “Energy-Management Gap" in U.S. manufacturing: Spillovers from firm management practices to energy efficiency. Journal of Environmental Economics and Management, 68, 463-479.

Bracke, R., Verbeke, T., Dejonckheere, V. (2008): What Determines the Decision to Implement EMAS? A European Firm Level Study. Environmental and Resource Economics, 41, 499-518.

Brand, J., Xie, Y. (2007): Identification and Estimation of Causal Effects with Time-Varying Treatments and Time-Varying Outcomes. Sociological Methodology, 37, 393-434.

Brouhle, K., Griffiths, C., Wolverton, A. (2009): Evaluating the role of EPA policy levers: An examination of a voluntary program and regulatory threat in the metal-finishing industry. Journal of Environmental Economics and Management, 57, 166-181.

Brouhle, K., Ramirez Harrington, D. (2010): GHG Registries: Participation and Performance Under the Canadian Voluntary Climate Challenge Program. Environmental and Resource Economics, 47, 521-548.

Bui, L., Kapon, S. (2012): The impact of voluntary programs on polluting behavior: Evidence from pollution prevention programs and toxic releases. Journal of Environmental Economics and Management, 64, 31-44. 
Carrión-Flores, C.E., Innes, R., Sam, A. (2013): Do voluntary pollution reduction programs (VPRs) spur or deter environmental innovation? Evidence from 33/50. Journal of Environmental Economics and Management, 66, 444-459.

Dasgupta, S., Hettige, H., Wheeler, D. (2000): What improves environmental compliance? Evidence from Mexican industry. Journal of Environmental Economics and Management, 39, 39-66.

Dehejia, R. H., Wahba, S. (2002): Propensity Score Matching Methods for Nonexperimental Causal Studies. The Review of Economics and Statistics, 84(1), 151-161.

EMAS Register: http://www.emas-register.de/. [10.01.2019].

European Environment Agency (2008). Environmental Agreements - Environmental Effectiveness. Summary - Case Study 3: Germany. https://www.eea.europa.eu/publications/92-9167-052-9sum/page006.html [10.01.2019].

Federal Environment Agency (2013): EMAS in Germany - Evaluation 2012. https://www.umweltbundesamt.de/publikationen/emas-in-germany-evaluation-2012 [10.01.2019].

Federal Environment Agency (2008): Bestimmung spezifischer Treibhausgas-Emissionsfaktoren für Fernwärme. $\quad$ https://www.umweltbundesamt.de/publikationen/bestimmung-spezifischertreibhausgas [10.01.2019].

Federal Environment Agency (2016a): Carbon Dioxide Emissions for the German Atmospheric Emission Reporting. https://www.umweltbundesamt.de/themen/klima-energie/treibhausgas-emissionen [10.01.2019].

Federal Environment Agency (2016b): Entwicklung der spezifischen Kohlendioxid-Emissionen des deutschen Strommix in den Jahren 1990 bis 2015. https://www.umweltbundesamt.de/publikationen/entwicklung-der-spezifischen-kohlendioxid-2 [10.01.2019].

Federal Environment Agency (2017): https://www.umweltbundesamt.de/themen/wirtschaftkonsum/wirtschaft-umwelt/umwelt-energiemanagement/iso-14001umweltmanagementsystemnorm\#textpart-4 [10.01.2019].

Federal Ministry for Economic Affairs and Energy (2014): National Action Plan on Energy Efficiency. Online: $\quad$ https://www.bmwi.de/Redaktion/DE/Publikationen/Energie/nationaler-aktionsplanenergieeffizienz-nape.html [10.01.2019].

Fisher-Vanden, K., Thorburn, K. (2011): Voluntary corporate environmental initiatives and shareholder wealth. Journal of Environmental Economics and Management, 62(3), 430-445.

Fleiter, T., Gruber, E., Eichhammer, W., Worrell, E. (2012a): The German energy audit program for firms - a cost-effective way to improve energy efficiency? Energy Efficiency, 5, 447-469.

Fleiter, T., Schleich, J., Ravivanpong, R. (2012b): Adoption of energy-efficiency measures in SMEs-An empirical analysis based on energy audit data from Germany. Energy Policy, 51, 863-875.

Fowlie, M., Holland, S. P., Mansur, E. T. (2012): What Do Emissions Markets Deliver and to Whom? Evidence from Southern California's NOx Trading Program. American Economic Review, 102(2), 96593.

Frondel, M. Horbach, J., Rennings, K., Requate, T. (2004): Environmental Policy Tools and Firm-Level Management Practices: Empirical Evidence for Germany. Economics working paper / Christian- 
Albrechts-Universität Kiel, Department of Economics, No. 2004, 02. Working Paper available at https://www.econstor.eu/handle/10419/21979. [10.01.2019].

Gamper-Rabindran, S. (2006): Did the EPA's voluntary industrial toxics program reduce emissions? A GIS analysis of distributional impacts and by-media analysis of substitution. Journal of Environmental Economics and Management, 52, 391-410.

Gerarden, T., Newell, R. G., Stavins, R. N. (2017): Assessing the Energy-Efficiency Gap. Journal of Economic Literature, 55(4), 1486-1525.

Gerster, A. (2017): Do Electricity Prices Matter? Plant-Level Evidence from German Manufacturing. Working Paper available at https://ssrn.com/abstract=2603211 or http://dx.doi.org/10.2139/ssrn.2603211 [10.01.2019].

Heckman, J. (1979): Sample Selection Bias as a Specification Error. Econometrica, 47, 153-161.

Heckman, J., Ichimura, H., Todd, P. E. (1997): Matching as an econometric evaluation estimator: Evidence from evaluating a job training programme. The Review of Economic Studies, 64(4), 605-654.

Heckman, J., Ichimura, H. Smith, J., Todd, P. E. (1998): Characterizing Selection Bias Using Experimental Data. Econometrica, 66, 1017-1098.

Ho, D.E., Imai, K., King, G. (2007): Matching as Nonparametric Preprocessing for Reducing Model Dependence in Parametric Causal Inference. Political Analysis, 15, 199-236.

lacus, S., King, G., Porro, G. (2011): Multivariate Matching Methods That Are Monotonic Imbalance Bounding. Journal of the American Statistical Association, 106, 345-361.

lacus, S., King, G., Porro, G. (2012): Causal Inference without Balance Checking: Coarsened Exact Matching. Political Analysis, 20(1), 1-24.

IEA (2015): Capturing the Multiple Benefits of Energy Efficiency. International Energy Agency Publication, https://www.iea.org/publications/freepublications/publication/capturing-the-multiplebenefits-of-energy-efficiency.html [10.01.2019].

IEA (2017): Energy Efficiency. International Energy Agency Market Report Series, https://www.iea.org/efficiency [10.01.201].

Iraldo, F., Testa, F., Frey, M. (2009): Is an environmental management system able to influence environmental and competitive performance? The case of the eco-management and audit scheme (EMAS) in the European Union. Journal of Cleaner Production, 17, 1444-1452.

Jaffe A. B., Stavins R.N. (1994): The energy-efficiency gap: what does it mean. Energy Policy, 22, 804810.

Khanna, M., Damon, L. (1999): EPA's Voluntary 33/50 Program: Impact on Toxic Releases and Economic Performance of Firms. Journal of Environmental Economics and Management, 37, 1-25.

Khanna, M., Anton, W. (2002): Corporate Environmental Management: Regulatory and Market-Based Incentives. Land Economics, 78(4), 539-558.

Kim, E.-H., Lyon, T. (2011): Strategic environmental disclosure: Evidence from the DOE's voluntary greenhouse gas registry. Journal of Environmental Economics and Management, 61, 311-326.

Kube, R., Capellen, P. (mimeo): Why do German manufacturing firms participate in EMAS? Results of an online survey. Not published but available upon request. 
Lutz, B. J. (2016): Emissions trading and productivity: Firm-level evidence from German manufacturing. ZEW Discussion Papers, No. 16-067. Working Paper available at https://ideas.repec.org/p/zbw/zewdip/16067.html [10.01.2019]

Löschel, A., Lutz, B. J., Managi, S. (2018): The impacts of the EU ETS on efficiency and economic performance - An empirical analyses for German manufacturing firms. Resource and Energy Economics, ISSN 0928-7655, https://doi.org/10.1016/i.reseneeco.2018.03.001 [10.01.2019]

Löschel, A., Lutz, B. J., Massier, P. (2017): Credit Constraints, Energy Management Practices, and Investments in Energy Saving Technologies: German Manufacturing in Close-Up (2017). ZEW - Centre for European Economic Research Discussion Paper, No. 17-072. Working Paper available at https://ssrn.com/abstract=3091625 or http://dx.doi.org/10.2139/ssrn.3091625 [10.01.2019].

Martin, R., Muûls, M., de Preux, L., Wagner, U. (2012): Anatomy of a paradox: Management practices, organizational structure and energy efficiency. Journal of Environmental Economics and Management, 63, 208-223.

Nakamura, S., Takahashi, T., Vertinsky, I. (2001): Why Japanese Firms Choose to Certify: A Study of Managerial Responses to Environmental Issues. Journal of Environmental Economics and Management, 42, 23-52.

Neugebauer, F. (2012): EMAS and ISO 14001 in the German industry - complements or substitutes? Journal of Cleaner Production, 37, 249-256.

Nishitani, K. (2011): An Empirical Analysis of the Effects on Firms' Economic Performance of Implementing Environmental Management Systems. Environmental and Resource Economics, 48, 569586.

Petrick, S., Wagner, U. (2014): The Impact of Carbon Trading on Industry: Evidence from German Manufacturing Firms. Working Paper available at http://ssrn.com/abstract=2389800 [10.01.2019].

Pizer, W. A., Morgenstern, R., Shih, J.-S. (2011): The performance of industrial sector voluntary climate programs: Climate Wise and 1605(b). Energy Policy, 39, 7907-7916.

Rennings, K., Ziegler, A., Ankele, K., Hoffmann, E. (2006): The influence of different characteristics of the EU environmental management and auditing scheme on technical environmental innovations and economic performance. Ecological Economics, 57, 45-59.

Research Data Centre of the Statistical Offices Germany: AFiD-Panel Industrial Units (DOI: 10.21242/42111.2014.00.01.1.1.0), AFiD-Module Use of Energy (DOI: 10.21242/43531.2014.00.03.1.1.0), AFiD Module Environmental Protection Investments (DOI: 10.21242/32511.2015.00.03.1.1.0 and 10.21242/32511.2005.00.03.1.1.0) for years 1995-2014, Further information: http://www.forschungsdatenzentrum.de/en/index.asp [10.01.2019].

Richter, P.M., Schiersch, A. (2017): CO2 Emission Intensity and Exporting: Evidence from firm-level data. European Economic Review, 98, 373-391.

Rosenbaum P., Rubin, D. (1983): The central role of the propensity score in observational studies for causal effects. Biometrika, 70, 1, 41-55.

Schleich, J., Fleiter, T. (2017): Effectiveness of Energy Audits in Small Business Organizations. Resource and Energy Economics. http://dx.doi.org/10.1016/i.reseneeco.2017.08.002 [10.01.2019]

Simcoe, T., Toffel, M. W. (2014): Government green procurement spillovers: Evidence from municipal building policies in California. Journal of Environmental Economics and Management, 68(3), 411-434. 
Videras, J. Alberini, A. (2000): The appeal of voluntary environmental programs: which firms participate and why? Contemporary Economic Policy, 18(4), 449-461.

Vidovic, M., Khanna, N. (2007): Can voluntary pollution prevention programs fulfill their promises? Further evidence from the EPA's 33/50 Program. Journal of Environmental Economics and Management, 53, 180-195.

Ziegler, A., Busch, T., Hoffmann, V. (2011): Disclosed corporate responses to climate change and stock performance: An international empirical analysis. Energy Economics, 33, 1283-1294. 


\section{Appendix}

\section{Appendix A: The EMAS Register sample}

The EMAS Register is an open access database provided by the Association of German Chambers of Industry and Commerce and provides a continuous register of EMAS participants. As of March 2016, we obtain a sample of 423 plants within 271 firms with at least 20 employees operating within large energy-consuming industries of the German manufacturing sector that were certified between 1995 and 2013. We do not include firms certified in 2014, as our dataset would not allow an investigation of post-certification outcomes for these firms. Specifically, we have selected firms within the following NACE 2-digit industry sectors:

17) Paper and paper products

19) Coke and refined petroleum products

20) Chemicals and chemical products

21) Pharmaceutical products

22) Rubber and plastic products

23) Other nonmetallic mineral products

24) Basic metals

25) Fabricated metal products

28) Machinery and equipment n.e.c.

29) Motor vehicles and trailers

Figure A1 shows the annual increase and stock of EMAS registration. Almost half of participants joined before the year 2000 and registration rates are much lower ever since. A spike in 2011 coincided with EMAS becoming an eligibility criterion for the reduced electricity tax rate.

Figure A1: Number of EMAS Registered plants per year (new registrations and stock) as of March 2016.

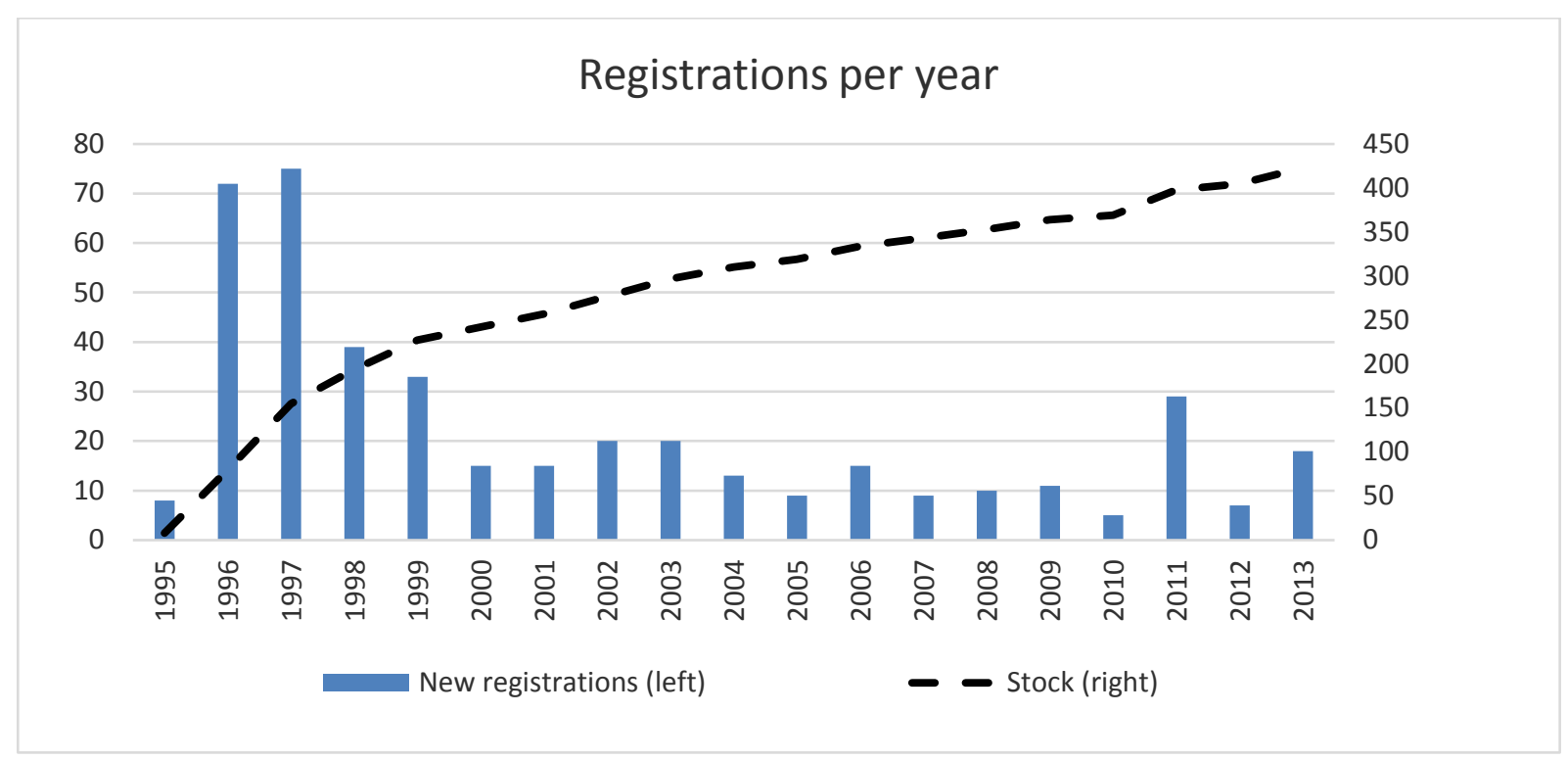

Note: (Source: EMAS Register). 


\section{Appendix B: Estimating direct $\mathrm{CO}_{2}$ Emissions of energy consumption}

The AFiD-Module Use of Energy provides consumption data for electricity and eight different fuel types, e.g. natural gas, oil and coal products.

We obtain fuel specific $\mathrm{CO}_{2}$ emission factors (see Table B1) by the Federal Environment Agency (Federal Environment Agency 2016a). In Table $\mathrm{B} 1$ we display the average $\mathrm{CO}_{2}$ emission factors over the years 1995-2014, whereas deviations across years and industries not shown for brevity.

The energy consumption variable for coal products, other mineral oil products and other gases are aggregated from more detailed fuels, which is why we weight the emission factor for each 3-digit industry and year according to the share the of subsumed fuels consumed in (AG Energiebilanzen).

For electricity purchased from the grid, we refer to the $\mathrm{CO}_{2}$ emission factor by the Federal Environment Agency (2016b) that accounts for international trade effects. Own generation of electricity is accounted for by the fossil fuel consumption.

We set the emission factor to zero for electricity from renewables (wind, solar, hydro) and other energy from renewable sources, e.g. usage of biofuels.

For district heating, we refer to values from the Federal Environment Agency (2008). Following the recommendation from a personal consultation of staff via phone in March 2017, we take the value of 2000 for 1995-2000, the value of 2005 for 2005-2014 and the mean of 2000-2005 for years 2001-2004.

Table B1: Mean $\mathrm{CO}_{2}$ emission factors over years 1995-2014 for specific energy carriers in the AFiD dataset.

\begin{tabular}{|l|c|}
\hline Fuel Type & Mean $\mathbf{C O}_{2} \mathbf{1 9 9 5 - 2 0 1 4}$ (g/kWh) \\
\hline Electricity (grid) & 620.100 \\
\hline Natural gas & 211.910 \\
\hline Light heating oil & 266.471 \\
\hline Heavy heating oil & 287.387 \\
\hline District heat & 217.920 \\
\hline Liquid gas & 234.599 \\
\hline Coal & 337.366 \\
\hline Coke & 389.268 \\
\hline Lignite raw & 387.877 \\
\hline Lignite briquetts & 356.699 \\
\hline Other mineral oil products & 279.387 \\
\hline Other gases & 441.425 \\
\hline Other coal products & 354.937 \\
\hline Other fuels and waste & 264.703 \\
\hline Renewables & 0 \\
\hline Note: (Source: Federal Environment Agency 2016a, 2016b, 2008, AG Energiebilanzen).
\end{tabular}




\section{Appendix C: Pre-trend check for $\mathrm{CO}_{2}$ intensity}

Prior to our results, we test the validity of the Difference-in-Differences estimation, which depends on the common trend assumption. In Table $\mathrm{C} 1$, we compare changes in $\log \mathrm{CO}_{2}$ intensity prior to the certification years across participation status. For example, row "1999" shows the change from 1995 to 1996 (column "t-4 -> t-3") and from 1996 to 1997 (column "t-3 -> t-2"), which is the time prior to firms' participation decision (less than two years according to Federal Environment Agency, 2013).

Overall, the t-tests for differences in mean trends are insignificant at the ten, five and one percent level ( $p$-values not shown in Table C1 for brevity). This endorses our Difference-in-Differences estimation approach and that matching on the covariates prior to the participation decision accounts for the problem of endogeneity.

Table C1: Pre-trends of $\log \mathrm{CO}_{2}$ Intensity for firms certified with EMAS in a given year and firms not certified in that year.

\begin{tabular}{|c|c|c|c|c|c|c|c|c|}
\hline \multicolumn{2}{|c|}{ Certification year } & \multirow[t]{2}{*}{$\begin{array}{c}t-4-> \\
t-3 \\
\end{array}$} & \multirow[t]{2}{*}{$\begin{array}{c}t-3-> \\
t-2 \\
\end{array}$} & \multirow{2}{*}{$\begin{array}{c}\begin{array}{c}t-2-> \\
t-1\end{array} \\
-0.03\end{array}$} & \multicolumn{2}{|c|}{ Certification year } & \multirow{2}{*}{$\frac{t-3}{0.23}$} & \multirow{2}{*}{$\frac{\mathbf{t}-\mathbf{2}}{-0.02}$} \\
\hline 1997 & Certified & & & & 2006 & Certified & & \\
\hline & Non-certified & & & 0.08 & & Non-certified & 0.16 & 0.06 \\
\hline \multirow[t]{2}{*}{1998} & Certified & & -0.03 & & 2007 & Certified & -0.02 & 0.01 \\
\hline & Non-certified & & -0.10 & & & Non-certified & -0.31 & -0.01 \\
\hline \multirow[t]{2}{*}{1999} & Certified & -0.03 & -0.06 & & 2008 & Certified & 0.01 & -0.02 \\
\hline & Non-certified & 0.07 & -0.10 & & & Non-certified & 0.08 & -0.03 \\
\hline \multirow[t]{2}{*}{2000} & Certified & -0.06 & 0.00 & & 2009 & Certified & -0.03 & -0.02 \\
\hline & Non-certified & -0.13 & -0.04 & & & Non-certified & -0.04 & -0.13 \\
\hline \multirow[t]{2}{*}{2001} & Certified & 0.00 & -0.02 & & 2010 & Certified & -0.03 & -0.02 \\
\hline & Non-certified & 0.05 & 0.01 & & & Non-certified & 0.14 & 0.06 \\
\hline \multirow[t]{2}{*}{2002} & Certified & -0.02 & -0.01 & & 2011 & Certified & -0.02 & 0.07 \\
\hline & Non-certified & -0.07 & -0.06 & & & Non-certified & -0.10 & 0.20 \\
\hline \multirow[t]{2}{*}{2003} & Certified & -0.01 & 0.06 & & 2012 & Certified & 0.07 & -0.01 \\
\hline & Non-certified & 0.05 & -0.04 & & & Non-certified & 0.27 & -0.14 \\
\hline \multirow[t]{2}{*}{2004} & Certified & 0.06 & 0.00 & & 2013 & Certified & -0.01 & -0.07 \\
\hline & Non-certified & 0.10 & -0.11 & & & Non-certified & -0.02 & -0.17 \\
\hline \multirow[t]{2}{*}{2005} & Certified & 0.00 & 0.23 & & & & & \\
\hline & Non-certified & -0.07 & 0.06 & & & & & \\
\hline
\end{tabular}

Note: T-3 (t-2) are trends 3 (2) years prior to the respective certification year. For firms certified in 1997 we can only include the change 1 year prior to certification. P values: *: $p<0.1$, **: $p<0.05, * * *: p<0.01$. (Source: Research Data Centre of the Federal Statistical Office and Statistical Offices of the Länder, Official Firm Data for Germany (AFiD) - AFiD-Panel Industrial Units, AFiD Module Use of Energy, AFiD Module Environmental Protection Investments, survey years 1995-2014, own calculations). 


\section{Appendix D: Estimating the Propensity Score of EMAS participation}

We estimate the Propensity Score, the probability to adopt EMAS in a given year $t$, based on the same lagged covariate vector $\mathbf{X}_{\text {ist' }}$ as for the CEM matching as:

$E M A S_{i s t}=F\left(\gamma \cdot \boldsymbol{X}_{i s t^{\prime}}\right)+\pi_{i s t}$,

where $F(\cdot)$ is the cumulative logistic distribution and $\pi_{i s t}$ is an i.i.d. error term.

Table D1 shows the respective logit estimation results.

Table 8: Results of the Logit estimation of the participation decision (Propensity Score specification).

\begin{tabular}{|c|c|c|}
\hline Dependent Variable & \multicolumn{2}{|c|}{ EMAS certification in given year } \\
\hline Sub-period & 1995-2002 & 2003-2014 \\
\hline $\mathrm{CO}_{2}$ Intensity (In) & $\begin{array}{l}-0.875 \\
(0.684)\end{array}$ & $\begin{array}{l}-3.127^{* *} \\
(1.305)\end{array}$ \\
\hline Energy $(\ln )$ & $\begin{array}{l}0.830^{* * *} \\
(0.158)\end{array}$ & $\begin{array}{l}0.804 * * * \\
(0.154)\end{array}$ \\
\hline Revenue & $\begin{array}{l}0.000 \\
(0.000)\end{array}$ & $\begin{array}{l}0.000 \\
(0.000)\end{array}$ \\
\hline Export Ratio & $\begin{array}{l}-1.950^{* *} \\
(0.925)\end{array}$ & $\begin{array}{l}-0.193 \\
(0.651)\end{array}$ \\
\hline $\begin{array}{l}\text { Fossil + Eco-Investments + } \\
\text { Renewables (dummy) } \\
\text { (all three dummy variables } \\
\text { comprised in one) }\end{array}$ & 0.000 & -0.501 \\
\hline $\begin{array}{l}\text { EEG exemption eligibility } \\
\text { (dummy) }\end{array}$ & $\begin{array}{l}-- \\
--\end{array}$ & $\begin{array}{l}0.061 \\
(0.545)\end{array}$ \\
\hline $\begin{array}{l}\text { Industry dummies } \\
\text { State dummies }\end{array}$ & $\begin{array}{l}\text { Yes } \\
\text { Yes }\end{array}$ & $\begin{array}{l}\text { Yes } \\
\text { Yes }\end{array}$ \\
\hline $\begin{array}{c}\text { N } \\
\text { Likelihood ratio } \\
\text { Prob > chi2 } \\
\text { Pseudo } \mathbf{R}^{\wedge 2}\end{array}$ & $\begin{array}{l}70,732 \\
77.95 \\
<0.0001 \\
0.1101\end{array}$ & $\begin{array}{l}148,165 \\
69.99 \\
<0.0001 \\
0.0792\end{array}$ \\
\hline
\end{tabular}

Note: Standard errors are i.i.d. We include a dummy that is equal to one if at least one of the dummy variables Fossil, Renewables or Eco-Investments is equal to one (the latter two are only available since 2003). P values: *: $p<0.1, * *: p<0.05$, ***: $p<0.01$ (Source: Research Data Centre of the Federal Statistical Office and Statistical Offices of the Länder, Official Firm Data for Germany (AFiD) - AFiD-Panel Industrial Units, AFiD Module Use of Energy, AFiD Module Environmental Protection Investments, survey years 1995-2014, own calculations). 
Download ZEW Discussion Papers from our ftp server:

http://ftp.zew.de/pub/zew-docs/dp/

or see:

https://www.ssrn.com/link/ZEW-Ctr-Euro-Econ-Research.html

https://ideas.repec.org/s/zbw/zewdip.html

$$
\text { // }
$$

IMPRINT

ZEW - Leibniz-Zentrum für Europäische Wirtschaftsforschung GmbH Mannheim

ZEW - Leibniz Centre for European

Economic Research

L 7,1 68161 Mannheim

Phone +49621 1235-01

info@zew.de·zew.de

Discussion Papers are intended to make results of ZEW research promptly available to other economists in order to encourage discussion and suggestions for revisions. The authors are solely responsible for the contents which do not necessarily represent the opinion of the ZEW. 